\title{
NU Women's Role In Narrating The Moderate Islam Through Majelis Taklim
}

\author{
Dr. Wiwi Siti Sajaroh, MA. \\ Faculty of Political and Social Science \\ State Islamic University Syarif Hidayatullah \\ Jakarta, Indonesia \\ sajaroh2006@yahoo.com \\ Sarah Hajar Mahmudah, S.Sos. \\ Faculty of Political and Social Science \\ State Islamic University Syarif Hidayatullah \\ Jakarta, Indonesia \\ Sarah.hajarm@gmail.com
}

\begin{abstract}
Majelis taklim is a non-formal institution for Muslims to learn about Islamic teaching. Nowadays, there are many majelis taklim that are filled by Islamic scholars who spread the teachings of radical Islam or takfiri ideology. It has become one of the methods of spreading radical ideology among Muslims. With the spread of takfiri ideology, majelis taklim produces people who dare to commit violence in the name of religion. Recently, the main actors of terror and suicide bombings are not only men, a few years ago women with radical Islamic ideology were limited to providing support to the actions of their husbands or family, but now women become the main suicide bombers. Nahdhatul Ulama (NU) is a bigger Muslim organization in Indonesia that is consistent in teaching the values of peaceful and moderate Islam, then how about NU women (Muslimat) role in monitoring the teachings of this ideology taught in many majelis taklim for women? This research figures out the role of Muslimat NU in fostering women's majelis taklim, to teach a peaceful and moderate narrative of Islam for women in Indonesia. This study compares the narratives of peace brought by Muslimat NU to counter the takfiri narratives in contemporary issues. Through this role, this study also analyzes the role of Muslimat NU as a large Muslim women's organization. This study uses a qualitative method by utilizing discourse analysis. The data is collected through observation, conversational analysis, and discourse analysis.
\end{abstract}

Keywords- Muslimat NU, majlis taklim, moderate Islam.

\section{INTRODUCTION}

Majelis taklim is an informal education institution for Muslims to explore the teaching of Islam. The formation of the Taklim assembly is rooted in the propagation movement of the Prophet who created a forum of religious discussion with his companions in the mosque. Awareness of the importance of studying refers to the hadith of the Prophet Muhammad which says "studying is obligatory Due to these obligations the community then set up public groups at the mosque, neighborhood and other places namely Majelis taklim. The term majlis taklim is derived from the Arabic مجلس / majlis (isim makan, meaning place) and the word جلس, يجلس, جلوسا which means the seat, place or meeting. While the word taklim / تعليم (isim masdar) means teaching, training is derived from the word علم, يعلم, علما which means knowing something, science, and meaning. Hence, majelis taklim refers to a place used for teaching and learning about Islam.

There are majelis taklim for men as well as for women which its distinctive organizational structure and discussion material. Majelis taklim for men are commonly located at the mosque, while the group for the usually takes place outside the mosque. For instance, in a madrasah, women typically conduct the meeting at the yard because they are not always able to enter the mosque due to the menstruation cycle. Even though the assembly can consist of both made of men and women, mostly the members of taklim assemblies are women. It is influenced by the social and cultural condition in Indonesia, especially regarding gender understanding among its society. In Indonesia, men dominate the commercial, industrial and business sectors while women usually handle the domestic works. Adding to that, religious teaching also further legitimize the division of the role; men are considered as the leaders of the family while women are the makmun (follower). Majelis taklim became a safe space for women to access the public sectors and actualize themselves. Majelis taklim allows women take a break from their routine as housewives and socialize with the other women outside their house.

According to the International Crisis Group (ICG), the popularity of Majelis taklim is due to two reasons. The first is the motivation for religious 
teaching, and the second is freedom of speech era after the fall of President Soeharto. A majelis taklim can be consisted of from tens up to thousands of members. The speakers are the key to the majlis taklim's sermon; they hold a position that allows them to promote moderation, fanaticism and other views of Islam. There are also religious groups that traverse the ideal majelis taklim try to use the association as a way of building membership, including the extremist groups. The freedom to make groups and study forums give the opportunity for the radical groups not only to get members but also to disseminate their ideology.

The fall of the authoritarian New Order government opened the chance of freedom of expression for all classes. Previously, the political aspirations and expressions were restrained by the regime, but after its fall opinion can be freely expressed, including the freedom to voice the Islamic movements. The rise of post-reformation Islam movement can be seen from the growing number of Islamic groups that fight for the Islamic Shari'ah, such as Front Pembela Islam (FPI), Hizbut Tahrir Indonesia (HTI), Majelis Mujahidin Indonesia (MMI). There also Tarbiyah Movement with PKS as its vehicle, and Communication Forum Ahlus Sunnah wal Jamaah with its Laskar Jihad. Furthermore, the transnational Islamic movement also emerged alongside the local Islamic movement. The various Islamic movements that emerged reflect the direct proportion of the kind of ideologies that these groups brought. It is ranging from the liberal, moderate to radical one, and it is not seldom the group contradict one another.

\section{WOMEN'S MAJELIS TAKLIM AND RADICAL IDEOLOGY}

Most of the radicalism and terrorism case show how a woman becomes a wife who supports the action her extremist husband. One of the examples is a terrorism case in Pekalongan which involves SU whose husband, FR was accused of being a terrorist. SU's family has reminded her not to follow her husband's ideology which is considered as the terrorism by the Indonesia government. However, SU herself has her own interpretation of what is called as a terrorist. She thinks the real terrorists are the ones who accuse others of terrorists like the United States and its allies. The Majelis taklims lecture that she followed shaped her opinion on terrorism. The sermon that she attended explains that a good Muslim is the one who can feel the pain of the fellow Muslim. The lecture used Iraq, Afghanistan, Palestine to Ambon as an example of the suffering Muslims. The perpetrators who caused the plight of the Muslims were alleged to the Jewish and Kafir who were supported by the United States. With such a defense it is fair to believe that SU supports her husband to commit the acts of terrorism, in this case, to fight the enemies of Islam that is America as suicide bombings are often addressed to America and its capitalism.

In the past, women were responsible for a behind the scenes role in a terrorist act. They are responsible for managing social media, setting up fund-raising agencies, and conducting other forms of logistical support. Nowadays, their role changes from the behind-the-background actor to become the lead actor in a suicide bombing terror. In December 2016, two women were the suspects of the suicide bomb attack in Jakarta; they are Dian Yulia Novi and Ika Puspitasari aka Tasnima Salsabila. Both of them formerly worked as the female foreign migrant worker before their volunteer action for the bombing of Indonesia Presidential Palace in Jakarta. Following that case, in October and July 2016, other women namely Tini Susanti Kaduku and Jumaitun aka Ummi Delima were captured for their action as the combatant armed force alongside their husbands in the Mujahidin of East Indonesia (MIT).

Hizbut Tahrir Indonesia (HTI), a transnational Islamic organization that initiated the Khilafah view, is an example of the extreme Islamic organization that was dismissed by the Indonesian government in 2017. The organization promulgated its ideology through publication such as the book named Taqiyyuddin an-Nabhani and the bulletin Jum'at alIslam. In addition to the release of the publications, HTI also delivered preaching at the campus mosques, residential mosques, Friday sermons, and also the majelis taklim.

According to Prof. Dr. Asep Usman Ismail, M.Ag, professor of UIN Syarif Hidayatullah Jakarta, the role of an Ulama is critical in preventing the spread of the seeds of radicalism in the society. Therefore Majelis taklim has a very strategic part because it can affect the majority of the society through a direct contact. Prof. Asep opinion is reinforced by the high number of majelis taklim in Indonesia. The data of Religion Ministry of Indonesia reveals that there are 35,254 majelis taklim in 30 cities in Indonesia, with details as follows:

Figure 1. Majelis taklim numbers in Indonesia

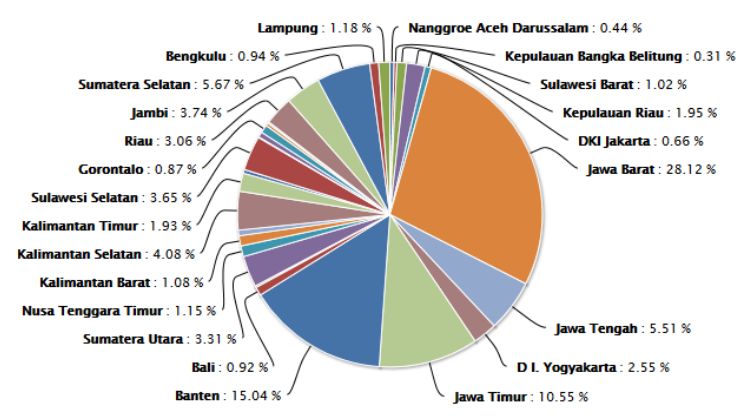




\section{NU WOMEN'S ROLE IN NARRATING MODERAT ISLAM WITH MAJELIS TAKLIM}

Nahdhatul Ulama is one of the largest Islamic organizations in Indonesia that has a significant the role in counter-narrative and deradicalization efforts in Indonesia. NU's position can not be separated from the long history of NU involvement in the process of Indonesian independence. Also, NU has four principles of value in the context of society and nationality which are very contrary to the radical interpretation of Islam. The first value is tawassuth (moderate) meaning that the view of $\mathrm{NU}$ is in the middle and not taking an extreme approach to doing something. Secondly, $i^{\prime}$ tidal (fair) which means to be fair and impartial. Third, tasamuh (tolerant) is the value that emphasizes tolerance to other religious views, culture, social community. Fourth, tawazun (harmony) which means keeping the balance among the devotion to Allah swt (hablumminallah), relationship with the fellow human (hablumminannas), and relationship with nature (hablumminal 'alam).

Muslimat NU, the autonomous body of NU, also shares the same basic principles. The trend of women in the terrorist movement has been a big concern to NU Muslims, as women and children also become victims of this radical dissemination. As a longstanding women's organization in Indonesia, NU Muslims have the potential to mobilize the majelis taklim. NU Muslimat has local branches which spread in 33 provinces in Indonesia. It consists of 525 districts chapters which have 4750 sub-districts chapters and 31,000 village chapters. NU Muslimat also has tens of thousands of female scholars (ustadzah) who have high charisma and wellrespected by the surrounding community. If $\mathrm{NU}$ Muslimat could manage to maximize this potential, it is possible that this organization can be a force to counter the spread of radicalism in the society and especially among the women who join majelis taklim in their neighborhood.

According to Khofifah Indar Parawangsa, the Chairman of PP Muslimat NU, women have a crucial role in warding off radicalism and spread the values of peace in the society. The members of Muslimat NU show an awareness that Majelis taklim can be the place for women to counteract the radicalism. To address the issue, the head of Muslimat NU in DKI Jakarta even made the Aswaja Muslimat NU program which aims to form a cadre that understands Ahlus Sunnah Wal-Jamaah. This personnel is assigned by the organization to convey NU religious understanding in the midst of urban society. There are 200 cadres from Muslimat NU DKI Jakarta that consist of teachers, ustadzah, young women and members of Fatayat NU also joins after the celebration of Ied in 2017. Hj. Hijbiyah Rochim, the daughter of NU founding father, KH Wahab Chasbullah, who is assigned as the Chairman of PW Muslimat NU DKI Jakarta mentioned that women could have a more significant role in this matter. The values of peace can be spread not by the preacher but also by the women themselves. Women also have a very crucial role considering their duty to nurture and educate their children at home.

Muslimat NU's cadre also collaborates with Badan Nasional Penanggulangan Terorisme (BNPT) in creating a program which aims prepare the ustadzah who can provide the moderate religious understanding among urban communities. All personnel who participated in the program has the responsibility also to train other members from all sub-division that the organization has. The follow-up is expected to create a chain of Aswaja cadres from the provincial to the villages level in DKI Jakarta area. In addition to Muslimat NU, other NU women autonomous body Fatayat NU also make $d a^{\prime} i$ educational prepare ustadzah who served to deliver anti-radicalism sermons in majelis taklim. Fatayat $\mathrm{NU}$ and BNPT inaugurated 500 anti-radical daiyah on April 21, 2017. These daiyah became partners of BNPT in overcoming radicalism. According to Anggia Ermarini, chairman of PP Fatayat NU, radicalism now becomes a new challenge because it also targets women and children. Hence, the program is expected to save women and children from radicalism. The role of women is significant due to their more intense and active participation in majlis taklim compared to the male members of the association. Also, women's role as a mother allows them to be the first to educate the children, so the teachings of moderate and peaceful Islam can be more easily spread to the younger generations.

The role of majelis taklim and ulama/ustadzah is also complemented by the guidance book of majelis taklim teachings issued by NU Muslimat. This book is a reference material that should be delivered by Muslim NU scholars to the congregation. The materials presented are about aqidah, fiqh, morals and special material ahlus sunnah wal jamaah. Aqidah includes the understanding of the pillars of faith (the faith in God, angels, holy books, and Allah's apostle of doomsday), also qada and qadar. Fiqih discusses the laws surrounding thaharah (holiness), prayer, zakat, fasting, funeral and mourning procession. The aim is to provide understanding to the congregation about the procedures, requirements, and the pillars of worship to be practiced in everyday life. The material of akhlak aims to give the knowledge to imitate the morals of the Prophet. The content of ahlus sunnah wal jamaah is material about the NU and Muslimat teaching. This content aims to provide knowledge to the congregation of ahlus sunnah wal jama'ah and the amaliah traditions performed by salafus shalih, 
who is also the characters of ahlus sunnah wal jamaah namely tawassuth, tawazun, i'tidal and amar ma'ruf nahi munkar. It differs from radical Islamic organizations which tend to initiate a discussion on the discussion of fiqh jihad and siyasah (politics) as well as the veil. It makes the congregation focuses on political discussion and support the system of Khilafah. The spirit of jihad also considers appearance (using hijab) the symbol of someone's piety.

\section{CONCLUSION}

Majelis Taklim functions a place for Muslim to study and also to spread kinds of Islamic ideology which may also include the radical and the extreme one. Muslimat NU as a women's organization has a vital role in providing the moderate Islamic narrative for the society. The part of Muslim NU is so essential considering the increasing number of ustadzah who spread the radical ideology through majelis taklim. The ustadzah of NU Muslim cadres become role models in the community and to maximize their impact, Muslimat NU organized a training program for cadres Aswaja to equip these ustadzah with a good understanding of moderate Islam. The potential of this organization is also strengthened by the spread of its branches and chapter at the local level. It can be a great force to instill the counteract to radicalism through the majelis taklim.

\section{Reference}

[1] ___ ,Pedoman Majelis Ta'lim,” Kementrian Agama RI, Jakarta, 2012. Page 1-2.

[2] Dini Anitasari, Fatimah Hasan, dkk, "Perempuan dan Majelis taklim: Membicarakan Isu Privat melalui Ruang Publik Agama," [Research Report] Rahima, 2010, page $9-10$

[3] , "Violent Extremism and Insurgency in Indonesia," [A Risk Assessment], USAID (United States Agency International Development), Januari 2013, page 5.

[4] Ahmad Syafi'i Mufid, "Perkembangan Paham Keagamaan Transnasional di Indonesia," Kementrian Agama RI, Jakarta, 2011, page 4.

[5] Maghfur, Siti Mumun Muniroh, "Woman Behind Terrorists (Religious, Self Adaptation and HusbandWife Relationship within Suspected Terrorists Family in Pekalongan)," Jurnal “Analisa" Volume 20 No. 02 December 2013, page 184-185.

[6] , "Mothers to Bombers: The Evolution of Indonesian Women Extremists," Institute for Policy Analysis of Conflict (IPAC), [Report], has been accessed on Saturday August 19 1 , 2017, from http://file.understandingconflict.org/file/2017/01/IPA C_Report_35.pdf

[7] Fernan Rahadi, "Peran Ulama Sangat Penting untuk Lawan Radikalisme," has been accessed on Saturday $19^{\text {th, }} \quad 2017, \quad$ from http://www.republika.co.id/berita/nasional/umum/16/0 9/16/odl5ks291-peran-ulama-sangat-penting-untuklawan-radikalisme
[8] Majelis taklim Data Base, Religion Ministry of Indonesia, has been accessed on Saturday August $19^{\text {th }}$, 2017, from http://simpenais.kemenag.go.id/majelis

[9] Saefudin Zuhri, "Deradikalisasi Terorisme: Menimbang Perlawanan Muhammadiyah dan Loyalitas Nahdlatul Ulama," Daulat Press, Jakarta, 2017. Page. 81-82.

[10] Fer, "Peran Perempuan Penting untuk Menangkal Radikalisme," has been accessed on Saturday $\quad 19^{\text {th }}, \quad 2017, \quad$ from http://www.beritasatu.com/gaya-hidup/310496-peranperempuan-penting-untuk-menangkalradikalisme.html

[11] Abdullah Alawi, "Muslimat NU DKI Jakarta Siapkan 200 Kader Aswaja untuk Majelis taklim," has been accessed on Saturday August 19 ${ }^{\text {th }}, 2017$, from http://www.nu.or.id/post/read/78010/muslimat-nu-dkisiapkan-200-kader-aswaja-untuk-majelis-talim\#

[12] , "BNPT dan Fatayat NU Melantik 500

Daiyah Anti Radikalisme Fatayat NU," has been accessed on Saturday August 19 $19^{\text {th }}$ 2017, from http://www.tribunnews.com/nasional/2017/04/21/bnpt -dan-fatayat-nu-melantik-500-daiyah-antiradikalisme-fatayat-nu

[13] _ _Buku Panduan Pengajaran Himpunan Da'iyah Dan Majelis Ta'lim Muslimat (HIDMAT) Nahdhatul Ulama,” PP Muslimat NU, Jakarta, 2014. 